\section{Editor-in-Chief}

Prof. Dr.-Ing. Thomas Böllinghaus

\section{Associate Editors}

Prof. Dr. M. Hentschel,

Dr. rer. nat. et Ing. habil. G.-R. Jaenisch, Prof. Dr.-Ing. Th. Kannengießer,

Dr.-Ing. A. Hofmann-Böllinghaus

\section{Journal Management}

Bettina Chang

Tel. +49 $3026005-356$

Fax +49 $3026005-250$

E-mail: bettina.chang@degruyter.com

\section{Media Sales}

Markus Kügel

Tel. +49 8976 902-424

E-mail: markus.kuegel@degruyter.com

\section{ARTICLES}

J.-O. Sass, A. Jakobi, A. Mitrovic, C. Ganz, J. Wilken, U. Burmeister, H. Lang,

R. Bader and D. Vogel

ఠ 593

Bending strength of ceramic compounds bonded with silicate-based glass solder

M. E. Çetin, G. Polat, M. Tekin, A. B. Batibay, and H. Kotan

Effect of $Y$ addition on the structural transformation and thermal stability

of Ti-22Al-25Nb alloy produced by mechanical alloying

J. Liu, J. Wang, H. Qi and Huiqin Chen

Grain evolution during hot ring rolling of as-cast 42CrMo ring billets

Yinghao Cui, Zhengzhou, Zhang Jianlong and Xue He

DCPD and strain gauge based calibration procedure for evaluation of low temperature creep behavior

W. Li, J. Zhang, P. Xin, Z. Wen, H. Jing, L. Zhao, L. Xu and Y. Han

Corrosion behavior of the heat affected zone in a $316 \mathrm{~L}$ pipeline weld

A. Hilger, N. Kardjilov, A. Lange, A. Kupsch, M. P. Hentschel, and I. Manke

Neutron darkfield imaging of fiber composites

M. Kaptanoglu and M. Eroglu

Investigation of in situ synthesized $\mathrm{TiB}_{2}$ particles in iron-based composite coatings processed by hybrid submerged arc welding

Y. Ayaz and S. Citil

Mechanical behavior of butt curved adhesive joints subjected to bending

S. O. Eruslu

Finite element modeling of glass particle reinforced epoxy composites under uniaxial compression and sliding wear

E. Kurtulus, I. Sapmaz and F. Karpat

Effect of the cooling process on the mechanical properties and microstructural behavior of extruded AZ31 and AM50 Mg alloys

U. Arabaci and S. Turan

Weldability of austempered rail steel using the flash-butt process

V. Pattusamy, R. Ilamurugan, M. Govindaraj and A. Kasi

Effect of tool diameter ratio on the microstructural characteristics of a solid-state processed aluminum based metal matrix compositegy

T. Koca

A density measurement device for solid objects with uneven geometry

D. Jagadeesh, R. Venkatachalam and G. Nallakumarasamy

Experimental and numerical study of an overlay composite absorber plate material for a solar air heater
681

\section{DE GRUYTER}

Walter de Gruyter GmbH Genthiner Straße 13

10785 Berlin

Germany

www.materialstesting.de www.degruyter.com 


\section{Materials Testing Materialprüfung}

\section{Editorial Board/Beirat}

Prof. Dr. Suresh Babu

University of Tennessee, Oak Ridge National Laboratory, USA

Dr.-Ing. Manfred Bacher-Höchst

Robert Bosch GmbH, Stuttgart, Germany

Dr.-Ing. Martin Brune

Chair DVM, Germany

Prof. Dr. Y. Frank Chen

The Pennsylvania State University, Middletown, PA, USA

Prof. Dr. Carl E. Cross

Estes Park, Colorado, USA

Prof. Dr. Dan Eliezer

Ben Gurion University of the Negev, Israel

Prof. Dr.-Ing. Norbert Enzinger

TU Graz, Austria

Prof. Dr.-Ing. G. Lonthongkum

Chulalongkorn University, Bangkok, Thailand

Prof. Dr.-Ing. Peter Mayr

TU Munich, Germany

Prof. Dr.-Ing. Andreas Neidel

Siemens Energy / TU Berlin, Germany

Dr. Matthias Purschke

DGZfP, Germany

Dr.-Ing. Hans-Jürgen Schäfer

VDI Materials Engineering, Germany

Prof. Dr.-Ing. Peter Starke

University of Applied Sciences Kaiserslautern, Germany

Prof. Dr.-Ing. Frank Walther

TU Dortmund, Germany

Prof. Dr. Ali Riza Yildiz

Uludag University, Bursa, Turkey

\section{Editing Institutions/Herausgeber}

DGZfP

Deutsche Gesellschaft für zerstörungsfreie Prüfung

German Society for Non-Destructive Testing

DVM

Deutscher Verband für Materialforschung und -prüfung German Association for Materials Research and Testing VDI-Materials Engineering

VDI, Gesellschaft Werkstofftechnik

\section{Associate Editors/Redaktion}

Prof. Dr.-Ing. Th. Böllinghaus (Editor-in-Chief)

Prof. Dr. Manfred Hentschel

Dr.-Ing. Anja Hofmann-Böllinghaus

Dr. rer. nat. et Ing. habil. Gerd-Rüdiger Jaenisch

Prof. Dr.-Ing. Thomas Kannengießer

\section{Submission of manuscripts}

Manuscripts should be submitted to the Editor-in-Chief Prof. Dr.-Ing. Th. Böllinghaus, mt@degruyter.com

\section{Indexed in/Gelistet in}

Science Citation Index Expanded ${ }^{\circledR}$

http://science.thompsonreuters.com

\section{All articles are peer-reviewed}




\title{
Materials Testing
}

\author{
Materialprüfung
}

\section{MASTHEAD}

\section{ABSTRACTED/INDEXED IN}

Science Citation Index Expanded ${ }^{\circledR}$

http://www.thompsonreuters.com

ISSN 0025-5300 • e-ISSN 2195-8572

All information regarding notes for contributors, subscriptions, Open access, back volumes and orders is available online at http://www.degruyter.com/mt

\section{EDITOR-IN-CHIEF}

Prof. Dr.-Ing. Thomas Boellinghaus (verantw.)

Helmut Schmidt University/

University of the Federal Armed Forces Hamburg

mt@degruyter.com

\section{PUBLISHER}

Walter de Gruyter GmbH,

Berlin/Boston, Genthiner Straße 13, 10785 Berlin, Germany

\section{JOURNAL MANAGER}

Bettina Chang, De Gruyter, Genthiner Straße 13, 10785 Berlin, Germany. Tel.: +49 (0)30 260 05-356, Fax: +49 (0)30 260 05-250, e-mail: bettina.chang@degruyter.com

\section{RESPONSIBLE FOR ADVERTISEMENTS}

Markus Kügel, De Gruyter,

Rosenheimer Str. 143, 81671 München, Germany.

Tel.: +49 8976 902-424,

e-mail: markus.kuegel@degruyter.com

(C) 2021 Walter de Gruyter GmbH, Berlin/Boston, Germany

\section{TYPESETTING}

Druckerei Joh. Walch GmbH \& Co, Im Gries 6, 86179 Augsburg, Germany

\section{PRINTING}

Franz X. Stückle Druck und Verlag e.K., Ettenheim, Germany 